\title{
Management of breast abscesses by ultrasound-guided needle aspiration and continuation of breastfeeding: a pilot study
}

\author{
virginie rigourd ${ }^{1}$, laure benoit ${ }^{1}$, marine driessen ${ }^{1}$, caroline charlier $^{1}$, emanuelle bille ${ }^{1}$, brune \\ pommeret $^{2}$, Elise Leroy-Terquem ${ }^{1}$, ms murmu ${ }^{1}$, agnes guyonnet ${ }^{1}$, nathalie baunot ${ }^{1}$, and \\ jean-yves seror ${ }^{1}$ \\ ${ }^{1}$ Necker-Enfants Malades Hospitals \\ ${ }^{2}$ Hospital Centre Gustave Tourcoing
}

October 14, 2020

\begin{abstract}
Background - In case of breast abscess, many patients stop breastfeeding on the advice of a health professional. Purpose - We reviewed our experience of treatment of lactating breast abscesses by ultrasound-guided aspiration and suggest an algorithm of their management. We also analyzed the continuation of breastfeeding of these patients after advices from trained teams. Materiel and methods - We conducted a retrospective study from April 2016 to April 2017, including 34 patients referred for a breast abscess during lactation at the Duroc Breast Imaging Center. Results - A single aspiration was sufficient in $64.3 \%$ of cases. The delay between the occurrence of the abscess and the indication for drainage was significantly higher for patients who have needed finally surgical drainage $(p=0,0031)$. There were no difference of size of abscesses between patients receiving needle aspiration alone and those who have undergone surgery $(\mathrm{p}=0,97)$. All patients who had been managed by needle aspiration continued breastfeeding after the treatment and $40 \%$ of the patients were still breastfeeding at 6 months. Conclusion - The management of lactating breast abscess by ultrasound-guided needle aspiration is an effective alternative to surgery. It appears to be effective regardless of the size of the abscess and is compatible with the continuation of breastfeeding. Our study has indeed shown that if they are well advised, the majority of patients continue breastfeeding so that it is essential that health professionals be better trained regarding the management of breastfeeding complication
\end{abstract}

\section{Hosted file}

Manuscrit abcesJOG.pdf available at https://authorea.com/users/367087/articles/486642management-of-breast-abscesses-by-ultrasound-guided-needle-aspiration-and-continuationof-breastfeeding-a-pilot-study

\section{Hosted file}

figures1.pdf available at https://authorea.com/users/367087/articles/486642-managementof-breast-abscesses-by-ultrasound-guided-needle-aspiration-and-continuation-ofbreastfeeding-a-pilot-study

\section{Hosted file}

figure2.pdf available at https://authorea.com/users/367087/articles/486642-managementof-breast-abscesses-by-ultrasound-guided-needle-aspiration-and-continuation-ofbreastfeeding-a-pilot-study

\section{Hosted file}


figure3.pdf available at https://authorea.com/users/367087/articles/486642-managementof-breast-abscesses-by-ultrasound-guided-needle-aspiration-and-continuation-ofbreastfeeding-a-pilot-study

\section{Hosted file}

figure4.pdf available at https://authorea.com/users/367087/articles/486642-managementof-breast-abscesses-by-ultrasound-guided-needle-aspiration-and-continuation-ofbreastfeeding-a-pilot-study

\section{Hosted file}

figures5.pdf available at https://authorea.com/users/367087/articles/486642-managementof-breast-abscesses-by-ultrasound-guided-needle-aspiration-and-continuation-ofbreastfeeding-a-pilot-study 